Abstracta Iranica

Revue bibliographique pour le domaine irano-aryen

Volume 34-35-36 | 2017

Comptes rendus des publications de 2011-2013

\title{
Rika Gyselen. The coins of 3rd Century Sasanian Iran and the Formation of Historical Criteria
}

\section{Barbara Kaim}

\section{(2) OpenEdition}

1 Journals

Édition électronique

URL : http://journals.openedition.org/abstractairanica/42321

DOI : 10.4000/abstractairanica.42321

ISSN : 1961-960X

\section{Éditeur :}

CNRS (UMR 7528 Mondes iraniens et indiens), Éditions de l'IFRI

\section{Référence électronique}

Barbara Kaim, «Rika Gyselen. The coins of 3rd Century Sasanian Iran and the Formation of Historical Criteria », Abstracta Iranica [En ligne], Volume 34-35-36 | 2017, document 44, mis en ligne le 30 juillet 2017, consulté le 26 septembre 2020. URL : http://journals.openedition.org/abstractairanica/42321 ; DOI : https://doi.org/10.4000/abstractairanica.42321

Ce document a été généré automatiquement le 26 septembre 2020.

Tous droits réservés 


\title{
Rika Gyselen. The coins of 3rd Century Sasanian Iran and the Formation of Historical Criteria
}

\author{
Barbara Kaim
}

\section{RÉFÉRENCE}

Rika Gyselen. « The coins of 3rd Century Sasanian Iran and the Formation of Historical Criteria ».e-Sasanika 15, 2011, $30 \mathrm{p}$.

1 Cet article peut certainement servir de manuel abrégé aux étudiants en numismatique. L'A. décrit l'approche méthodologique qu'elle a élaborée et appliquée au cours de la préparation des deux premiers volumes de la Sylloge Nummorum Sasanidarum. Le lecteur apprend ainsi les critères qui ont permis de distinguer les deux séries de monnaies frappées sous Shapur I, puis comment répondre aux questions où et quand les ateliers monétaires qui les ont émises étaient actifs. Parce que les seules analogies sont fournies par les premières monnaies qu'Ardashir I avait frappées dans le Fars avant son accession au trône impérial, l'A. suggère que les pièces de Shapur ont été fabriqués par un même atelier, peut-être à Estakhr. Le style de l'une des séries de Shapur I émise dans le Fars a été maintenu d'Ohrmazd I à Narseh, mais sous Wahram II au revers apparaît une figure qui porte une couronne murale identique à celle de Shapur I. Le choix iconographique de Wahram II semble avoir été dicté par le besoin de mettre l'accent sur sa place dans la lignée de son grand-père. C'est aux historiens qu'il revient d'expliquer les événements qui ont conduit à cette situation. 


\section{AUTEURS}

\section{BARBARA KAIM}

Université de Varsovie 